\title{
En mann med feber, urticaria, periorbitalt ødem og tørrhoste
}

\author{
Ved utredning av uavklart febersykdom er det viktig å kartlegge reise- \\ anamnese. Hvor har du vært og hva har du gjort? Her presenteres en \\ pasient med feber, påvirket allmenntilstand og uspesifikke symptomer \\ fra luftveier og hud. Nylig reise i tropisk område og eosinofili ledet raskt \\ mistanken i retning av parasittsykdom, men mangelfulle opplysninger om \\ eksposisjon gjorde utredningen initialt mer omfattende enn nødvendig.
}

\author{
Tore Stenstad \\ tore.stenstad@siv.no \\ Seksjon for infeksjon og hematologi \\ Medisinsk klinikk \\ Sykehuset i Vestfold \\ Tønsberg
}

En tidligere frisk mann i 40-årene henvendte seg til sykehuset på grunn av tilbakevendende episoder med frysninger og feberfølelse. Seks uker før hadde han kommet hjem fra et to ukers opphold i Øst-Afrika der han hadde deltatt i terrengsykling på landsbygda. Pasienten fortalte at han 2-3 uker etter hjemkomst utviklet kortvarige feberepisoder om kvelden. De siste ni dagene hadde det vært daglige frysninger, ledsaget av kraftig nattesvette, tørrhoste og ukarakteristisk hodepine.

Ved undersøkelse var pasienten afebril og respiratorisk og sirkulatorisk stabil. Det var ikke utslett, icterus eller generalisert glandelsvulst, og ingen nakkestivhet eller andre tegn til meningisme. Organstatus for øvrig var upåfallende. Røntgen thorax var normalt. Blodprøver viste CRP 50 (<5 mg/l), SR 24 (<20 mm), leukocytter 6,8 (3,5-8,8 $10^{9} / \mathrm{ll}$ med lett eosinofili $\left(0,9\right.$; ref $\left.<0,4 \cdot 10^{9} / \mathrm{l}\right)$, men for øvrig upåfallende differensialtelling. Laktatdehydrogenase (LD) var lett forhøyet, og øvrige biokjemiske prøver var normale. Hurtigtest for malaria var negativ, og det kunne ikke påvises plasmodier i tykk- og tynndråpe. Man fant heller ingen holdepunkter for trypanosomer ved tykkdråpeundersøkelse ved lav forstørrelse. Serologi med henblikk på Epstein-Barr-virus, cytomegalovirus og hiv var negative, likeledes polymerasekjedereaksjonstest (PCR-analyser) for Mycoplasma pneumoniae, Chlamydophila pneumoniae, kikhoste, influensa- og parainfluensavirus $i$ nasopharynxsekret. Pasienten ble sendt hjem uten spesifikk behandling og med avtale om snarlig poliklinisk kontroll.

Malaria bør alltid vurderes hos febrile pasienter som kommer hjem fra endemiske områder. Plasmodium falciparum har inkubasjonstid på inntil fire uker (1), og her hadde de første feberepisodene debutert innen et slikt tidsintervall. Pasienten hadde brukt atovakvon/proguanil som malariaprofylakse, men medga å ha glemt enkelte doser. Han hadde sovet innendørs og brukt myggnett. Normale verdier for hemoglobin, trombocyt- ter, reticulocytter samt negativ malariahurtigtest og tykkdråpetest seks uker etter siste mulige eksposisjon, tilsa at malaria var en usannsynlig diagnose.

Tyfoidfeber er en annen alvorlig, importert febersykdom som tidlig bør utelukkes hos reisende. Denne tilstanden vil vanligvis debutere i løpet av de første 1-3 ukene etter hjemkomst (2). Pasienten rapporterte om tørrhoste, som kan ses ved tyfoid-/paratyfoidfeber. Selv om fravær av feber, trombocytopeni og leukopeni samt sparsom akuttfasereaksjon taler mot en slik differensialdiagnose, ble blodkulturer sikret. Disse forble sterile.

Akutt hivinfeksjon bør også vurderes hos pasienter som presenterer febril utslettsykdom etter opphold i et høyendemisk land. Fravær av makuløst eksantem, faryngitt og lymfadenopati talte mot en slik diagnose, og pasienten anga heller ingen seksuell eksposisjon. Denguefeber forventes også å gi makuløst eksantem samt myalgier og trombocytopeni (3). Denne diagnosen var derfor lite sannsynlig.

Trypanosomiasis (østafrikansk sovesyke) er særdeles sjelden i Norge (4), og pasienten kunne ikke erindre å ha blitt bitt av tsetsefluer. Det var heller ingen tegn til primærutslett i huden, meningisme eller sensorisk påvirkning. Protozosykdommer som malaria og trypanosomiasis gir vanligvis heller ikke eosinofili (5). Vår pasient hadde lett eosinofili. Akutt schistosomiasis (katayamafeber) gir oftest eosinofili (6), men ble funnet mindre sannsynlig fordi pasienten anga manglende ferskvannseksponering, inkubasjonstiden før feberdebut vanligvis er lenger enn i dette tilfellet samt at eosinofilien ofte er mer uttalt.

Pasienten kom til ny vurdering ved infeksjonsmedisinsk poliklinikk etter få dager. Han hadde målt kveldstemperaturer opptil $38,4^{\circ} \mathrm{C}$ og var afebril om morgenen. Han beskrev også flyktig elveblest over høyre flanke, men utslett kunne ikke observeres ved klinisk undersøkelse. Anamnestisk fore- 
4 Infeksiøse larver (cercarier) skilles ut fra sneglen til vann hvor den svømmer fritt

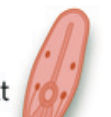

Larven mister halen idet den penetrerer huden

(3) Sporocyster i sneglen (mange generasjoner)

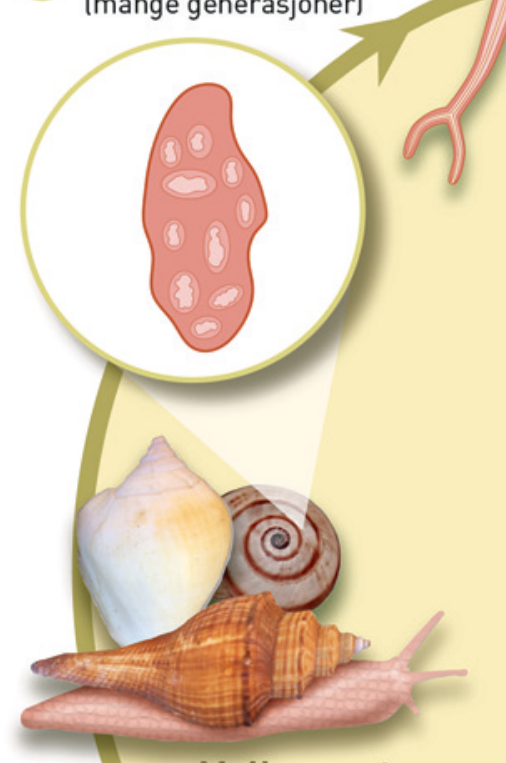

Mellomvert

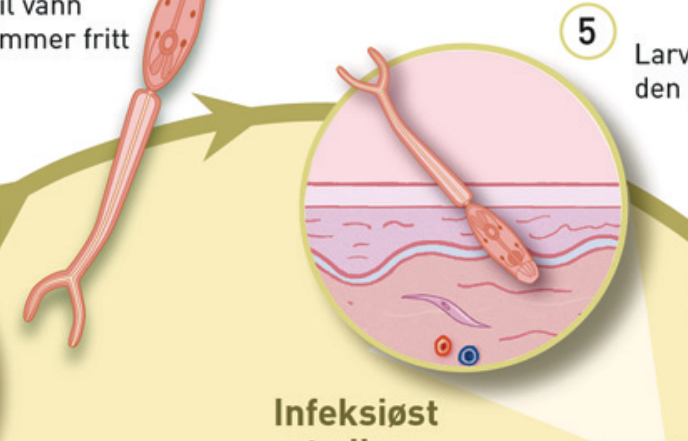

Infeksiøst

stadium

8 I leveren modnes larven og blir voksen

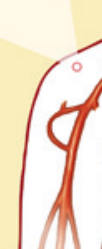

2 Eggene klekker og slipper ut miracidier som svømmer og infiserer snegler

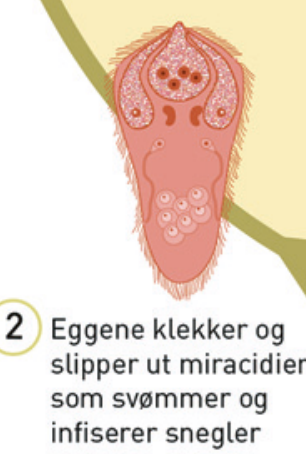

1 S. mansoni og S. intercalatum finnes i venepleksus $i$ gastrointestinalkanalen

9 Larven finner veien til venepleksus i urinveier og genitalia eller gastrointestinalkanalen

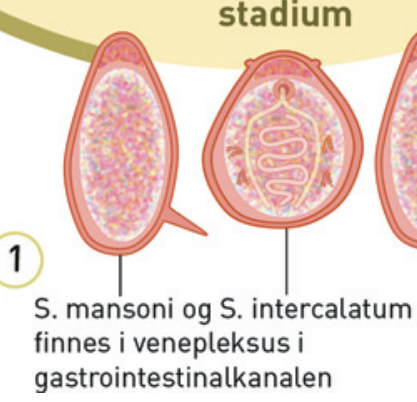

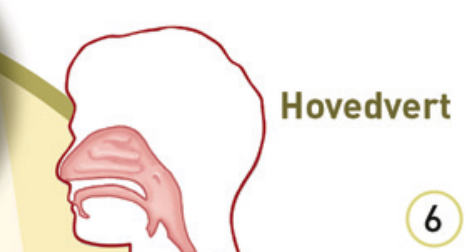

(6)

Larven blir til schistosomulum
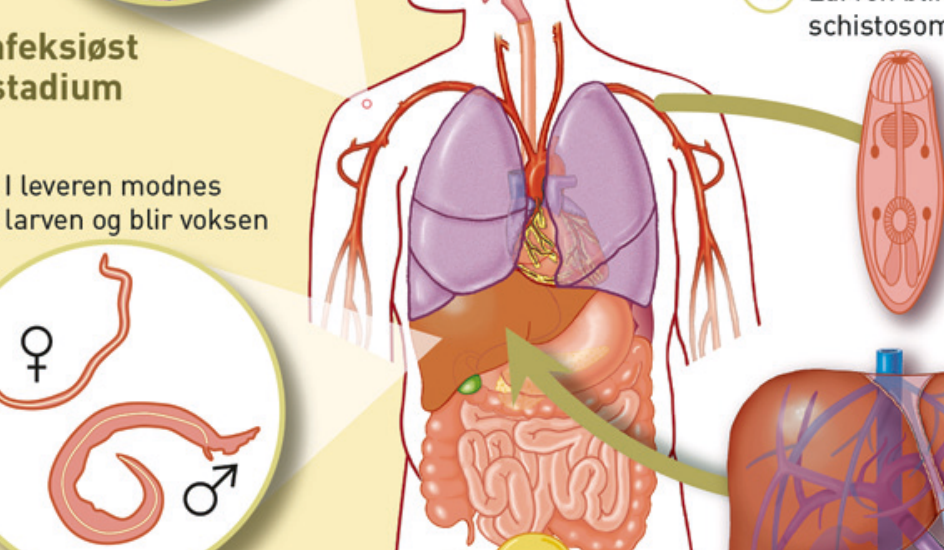


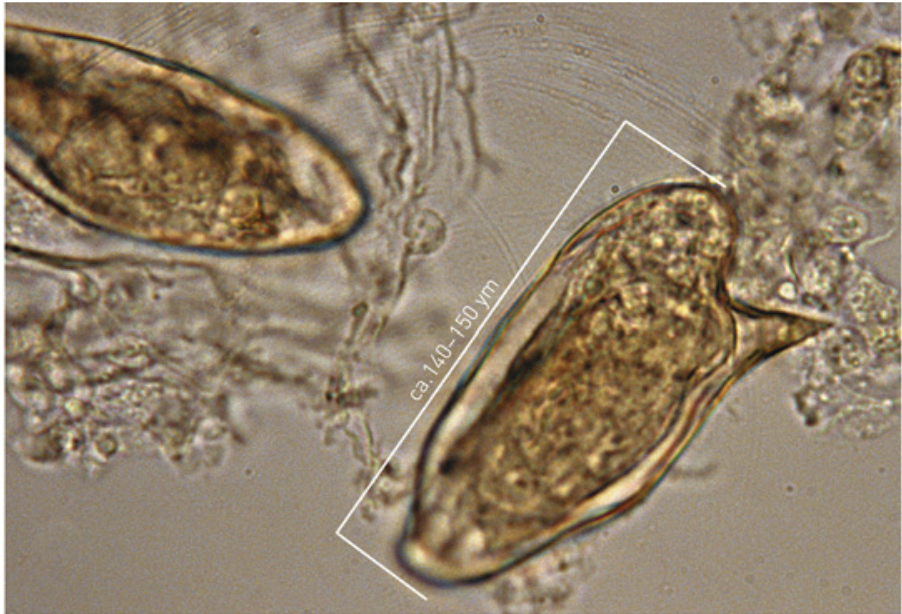

a

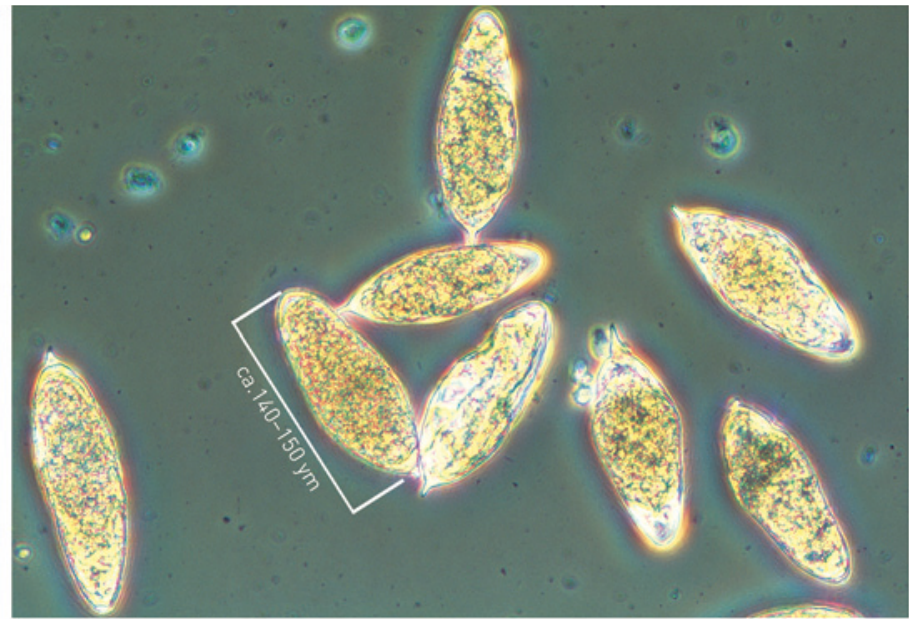

b

Figur 2 a) Egg fra S. mansoni. Foto: Corbis/Scanpix. b) Egg fra S. haematobium. Foto: Science Photo Library

lesjoner som årsak til hodepine og symptomer fra øynene. Spinalvæsken varfysiologisk. MR av caput viste litt væske i venstre mastoidalceller, tolket som uspesifikk inflammasjonspåvirkning. Ellers var det ingen lesjoner $i$ hjerne eller orbitae. Røntgen thorax viste sparsomme, smånodulære infiltrater, og CT av thorax, abdomen og bekken viste multiple, nodulære fortetninger $i$ lungeparenkymet, stedvis diffust avgrensede. Det ble også påvist multiple, små lavattenuasjoner perifert i høyre leverlapp av uviss årsak, og enkelte små lymfeknuter langs høyre hovedbronkie, men ingen lymfadenopati for øvrig. Milten var upåfallende. Funnene ved spirometri og gassdiffusjonstest var normale.

Under sykehusoppholdet ble det ikke funnet holdepunkter for bakteriell eller viral infeksjonssykdom eller affeksjon av sentralnervesystemet. Allmenntilstanden og vitale parametere var stabile, mens det urtikarielle utslettet kom og gikk. Mistanken om parasittsykdom med hud-, lunge- og mulig leveraffeksjon forårsaket av rundorm eller flatorm (bendelorm og ikter) var sterk.

Pneumoni forårsaket av flercellede parasitter kan skyldes direkte invasjon gjennom inhalasjon, hematogen/lymfatisk spredning eller ved eosinofil akkumulering som respons på helmintinfeksjon i inkubasjonsfasen (Löfflers syndrom) (7). I lys av radiologiske funn ble sistnevnte vurdert å være den mest sannsynlige tilstanden hos vår pasient. De vanligste årsaker til Löfflers syndrom er rundorminfeksjoner forårsaket av spolorm (Ascaris lumbricoides), hakeorm (Ancylostoma duodenale og Necator americanus) eller Strongyloides stercoralis. Også andre rundormer kan gi tilsvarende lungesykdom (visceral larva migrans, trikinose, dirofilariasis). Av flatormer som kan gi lungeaffeksjon, kan ekinokokkose nevnes. Verken pulmonal cys- tisk hydatidose (E. granulosus) eller alveolær ekinokokkose (E. multilocularis) passet med inkubasjonstid eller kliniske og radiologiske funn hos denne pasienten. Av ikter som kan gi lungeaffeksjon, er paragonimus- eller schistosomaarter de viktigste. Førstnevnte overføres ved inntak av rå skalldyr, men vår pasient hadde verken spist sushi eller annen sjømat uten tilstrekkelig varmebehandling under Afrika-oppholdet.

Svar fra Smittskyddsinstituttet (i dag: Folkhälsomyndigheten) i Stockholm kom under sykehusoppholdet, og det ble ikke påvist serologiske holdepunkter for infeksjon forårsaket av Strongyloides, Toxocara, Trichinella, Fasciola eller Filaria. Det kunne imidlertid påvises antistoffer mot Schistosoma $i$ to analyser $i$ et panel bestående av tre ulike antigener (tarmantigen immunfluorescens 2430 ( $10 \mathrm{U}$ ); eggantigen ELISA 52 ( $10 \mathrm{U}$ ); somatisk antigen immunfluorescens negativ). Tilstanden ble oppfattet som akutt schistosomiasis, og pasienten fikk først symptomatisk behandling med antihistaminer og steroider (prednisolon 20 mg daglig i én uke) med symptomlindrende effekt. Ved snarlig poliklinisk kontroll fikk pasienten spesifikk behandling med $3600 \mathrm{mg}$ praziquantel fordelt på to doser à 12 timers intervall. Det ble dessuten gjennomført mikroskopi av nye avføringsprøver samt konsentrert døgnurin uten at det ble funnet schistosomaegg.

Ved neste kontroll seks uker senere var pasienten fortsatt sykmeldt. Han fortalte om vedvarende fatigue, redusert treningstoleranse, astmasymptomer og enkelte episoder med urtikarielle hudutslett. CRP og eosinofile celler var normalisert. Man valgte å gjennomføre rebehandling med praziquantel $i$ doser som tidligere. Pasienten opplevde deretter langsom bedring.

Ved kontroll to år etter primærbehandlin- gen hadde pasienten fremdeles noe fatigue og lungesymptomer som responderte på inhalasjonssteroider. Det hadde også vært et fåtall utbrudd av urtikaria, men blodprøver var normale. CT-undersøkelse fra hals til bekken ble også kontrollert, og med unntak av en $2 \mathrm{~mm}$ stor nodulær lesjon i venstre lunge, kunne det ikke påvises patologi. Serologisk kontroll viste nå negativ ELISA-analyse med tanke på schistosomaeggantigen og betydelig titerfall for schistosomatarmantigen (2 430-810 U). Pasienten tilfrisknet siden.

\section{Diskusjon}

Kombinasjonen av feber, hoste, urtikarielt utslett, periorbitalt ødem, smånodulære, diffuse lungefortetninger og eosinofili etter opphold i Afrika reiste hos denne pasienten mistanke om parasittsykdom. Eosinofili og Löffler-symptomer ses verken ved malaria eller andre protozoinfeksjoner (5) og er forårsaket av helmintsykdommene i inkubasjonsfasen (7). Det er likevel viktig å utelukke alvorlige febrile importsykdommer slik som falciparummalaria og tyfoidfeber, ettersom eosinofili kan tenkes å ha andre årsaker, blant annet legemiddelreaksjon (f.eks. malariaprofylakse). Eksposisjon, klinisk bilde og sterkt positiv schistosomaserologi indikerte imidlertid at pasienten hadde katayamafeber, dvs. akutt schistosomiasis.

Schistosomiasis, også kjent som bilharzia, er en tropisk parasittsykdom forårsaket av en $10 \mathrm{~mm}$ lang flatorm (ikte) av slekten Schistosoma. Fem arter forårsaker sykdom hos mennesker: S. mansoni, S. japonicum, $S$. mekongi og S. intercalatum som gir en hepatointestinal form, samt $S$. haematobium som gir urogenital sykdom. Det anslås at mer enn 207 millioner er infiserte, hvorav $85 \%$ i Afrika der sykdomsbyrden er særlig høy (8). Sykdommen gir tap av 70 millioner sykdomsjusterte leveår, sammenliknbart med 
malaria, tuberkulose og hiv. Samtidig er sykdommen ofte omtalt som neglisjert, ettersom under $5 \%$ får behandling mot infeksjonen (9).

Parasitten har en komplisert livssyklus (fig 1). Mennesket er hovedvert og ferskvannssnegler mellomvert. Befruktede egg skilles ut med avføring eller urin. I ferskvann gjennomgår eggene en modning til infeksiøse larver (cercarier) som penetrerer huden til hovedverten og havner i leveren. Etter modning i leveren finner larven veien til venepleksus i urinveier og genitalia (S. haematobium) eller gastrointestinalkanalen (S. mansoni o.a.). Den voksne hannog hunnormen lever her sammen, formerer seg og skiller ut befruktede egg. Disse havner enten i miljøet eller blir sittende fast $i$ ulike vev der de induserer en granulomatøs inflammasjonsreaksjon. Dette gir over tid fibrose og organskade som dels er artsavhengig (10).

Schistosomiasis forekommer endemisk Midtøsten og Afrika mellom Sahara og Sør-Afrika, langs Nilen og på Madagaskar (S. haematobium, S. mansoni, S. intercalatum). I Sør-Amerika finnes $S$. mansoni langs den brasilianske kysten, mens $S$. japonicum finnes i Kina og Filippinene. S. mekongi er, som navnet tilsier, utbredt i Mekong-bassenget $(10-12)$.

Cercariedermatitt (svømmekløe) er en akutt, forbigående hypersensitivitetsdermatitt som opptrer kort tid etter at cercariene har penetrert huden. Vår pasient rapporterte ikke om slike symptomer.

I endemiske strøk er kronisk schistosomiasis den mest utbredte sykdomsformen og skyldes gjentatte eksposisjoner for infeksiøse cercarier. Den første infeksjonen inntreffer gjerne ved to års alder med økende parasittbyrde gjennom neste tiår for deretter å avta $\mathrm{i}$ voksenalder. I slike områder kan $60-80 \%$ av skolebarn og $20-40 \%$ av voksne være infiserte (10). Den kroniske sykdomsformen for $S$. mansoni presenterer seg med uspesifikke symptomer som magesmerter, diaré og rektalblødninger. Leverfibrose er oftest periportal og gir sjelden leversvikt. Portal hypertensjon med splenomegali og oesophagusvaricer opptrer imidlertid. S. haematobium gir urogenitale symptomer med hematuri og dysuri og leder i mange tilfeller til hydronefrose og nyresvikt. Infeksjonen gir også økt risiko for blærekarsinom, og både kvinnelig og mannlig genital schistosomiasis påvirker reproduktiv helse. Genitale lesjoner er antatt å forklare økt transmisjonsrate for hiv $(8,10)$.

Katayamafeber opptrer vanligvis hos ikke-immune som eksponeres for første gang og ved høyere alder enn hos fastboende $i$ endemiske strøk $(6,11)$. Tilstanden opptrer uker til måneder etter primærinfeksjon og er en følge av modning av ormene og eggproduksjon. Dette frisetter antigener i sirkulasjonen med en kraftig immunstimulerende effekt. Typisk klinisk presentasjon ved katayamafeber er akutt debut med feber, allmennpåvirkning, fatigue, myalgier, hodepine, magesmerter og eosinofili. Debut av feber opptrer 3-8 uker etter eksposisjonen, mens urtikaria kan opptre noe tidligere. Hoste, abdominalia og eosinofili tilkommer vanligvis etter feberdebut. Serokonversjon opptrer gjerne ikke før seks uker etter eksposisjon, mens eggutskilling i avføring eller urin starter enda senere $(10,11)$.

Lungeaffeksjon ved akutt schistosomiasis ble første gang rapportert for 60 år siden. Symptomer som hoste, tungpust og brystsmerter er beskrevet ved alle formene, men er vanligst ved $S$. mansoni-infeksjon (13). Patofysiologien er bare delvis forstått, men nedslag av immunkomplekser, eosinofil infiltrasjon og frisetting av proinflammatoriske cytokiner er sannsynligvis av betydning. Sjelden, men mer alvorlig, er affeksjon av sentralnervesystemet. Blant annet kan transvers myelitt som følge av ektopisk eggdeponering og inflammasjon, forekomme $(10,13)$

Diagnostikk av schistosomiasis avhenger av sykdomsstadium og parasittbyrde. Fremdeles utgjør mikroskopi av konsentrert urin og avføring gullstandard for diagnostikk av aktiv parasittsykdom (12), der karakteristiske egg påvises (fig 2). Fremfor alt gjelder dette hos personer med kronisk infeksjon. Hos ikke-immune reisende, og særskilt ved katayamafeber er parasittbyrden oftest så lav at mikroskopi gir negative funn (11). Malariaprofylakse med meflokin kan også redusere eggproduksjonen $(11,14)$.

En tidlig, lavgradig infeksjon påvises hovedsakelig ved antistofftester som er mer sensitive enn mikroskopi (6). Serologiske tester skiller ikke pågående fra tidligere sykdom $(10,13)$, og hos immigranter fra endemiske land kan dette representere en diagnostisk utfordring. Man vil imidlertid etter behandling forvente fallende antistofftitre, og behandling vil vanligvis tilbys personer fra endemisk område med positiv serologi med mindre det foreligger opplysninger om nylig behandling. Hos etnisk norske reisende er imidlertid bakgrunnsimmuniteten neglisjerbar. De fleste rutineteknikker påviser IgG, IgM eller IgE mot løselige orm- og eggantigener med ELISA-, immunhemagglutinineller immunfluorescensanalyser. Serokonversjon opptrer vanligvis 4-8 uker etter infestasjon, eventuelt lenger, og oftest etter symptomdebut. Vår pasient hadde positiv serostatus seks uker etter eksponering. Kombinasjon av flere tester brukes både for å øke sensitivitet og spesifisitet pga. kryssreaktivitet mellom schistosomaarter. Monoklonale antistofftester og Western blot har også vært benyttet for å oppnå høyere spesifisitet (11). Som hos vår pasient, må artsbestemmelse også vurderes ut ifra klinisk bilde, inkubasjonstid, epidemiologiske forhold og reiseanamnese, og infeksjonen har mest sannsynlig vært forårsaket av $S$. mansoni. Antigentester er også kommersielt tilgjengelige (15), men brukes lite $\mathrm{i}$ Norge fordi dette er sjeldne tilstander.

Påvisning av schistosoma-DNA gjennom molekylærgenetisk metodologi vil muligvis i fremtiden i noen grad erstatte mikroskopidiagnostikk, men er i dag vanskelig tilgjengelig for rutinediagnostikk.

Behandling av schistosomiasis har tre hovedintensjoner: reversere akutt og tidlig kronisk sykdom, forebygge vanlige komplikasjoner til kronisk infeksjon samt forebygge sjeldne, alvorlige komplikasjoner som nevroschistosomiasis. Praziquantel representerer førstehåndsbehandling $\mathrm{og} \mathrm{er}$ aktiv overfor alle arter (10-12). Virkningsmekanismen er ikke fullstendig forstått, men behandlingseffekt forutsetter et fungerende immunapparat. Midlet er ikke virksomt i det hele tatt overfor egg og lite overfor umodne larver. Behandlingen kan derfor vanligvis avventes til ca. seks uker etter eksposisjon. Alternativt kan rebehandling gjennomføres 4-6 uker etter primærbehandling for å fange opp larver under modning (11). Praziquantel fås på registreringsfritak som tabletter à $600 \mathrm{mg}$. Standarddosering er $40 \mathrm{mg} / \mathrm{kg}$ for $S$. mansoni og S. haematobium fordelt på 1-2 doser samme dag.

Artemisininderivater er i dag førstehåndsbehandling av alvorlig malaria, men midlene er også vist effektive overfor schistosomalarver. Det er indikasjoner for at kombinasjonsterapi øker behandlingseffekten sammenholdt med praziquantel alene $(12,16)$.

Ved katayamafeber kan steroider gis for å dempe hypersensitivitetsreaksjonen (12), men optimal behandlingslengde er ikke undersøkt i kontrollerte studier.

Pasienten har gitt samtykke til at artikkelen blir publisert.

\section{Tore Stenstad (f. 1966)}

er dr.med, spesialist i infeksjonssykdommer overlege og seksjonsleder

Forfatter har fylt ut ICMJE-skjemaet og oppgir ingen interessekonflikter. 


\section{Litteratur}

1. Askling HH, Bruneel F, Burchard G et al. Management of imported malaria in Europe. Malar J 2012. 11: 328 .

2. Crump JA, Sjölund-Karlsson M, Gordon MA et al. Epidemiology, clinical presentation, laboratory diagnosis, antimicrobial resistance and antimicrobial management of invasive Salmonella infections. Clin Microbiol Rev 2015; 28: 901-37

3. Gubler DJ. Dengue and dengue hemorrhagic fever. Clin Microbiol Rev 1998; 11: 480-96.

4. Myrvang B, von der Lippe B. Afrikansk trypanosomiasis - en sjelden importsykdom. Tidsskr Nor Lægeforen 2002; 122: 33-4.

5. Weller P, Klion A. Eosinophil biology and causes of eosinophilia. UpToDate. www.uptodate.com/ contents/eosinophil-biology-and-causes-ofeosinophilia? source=search result\&search= eosinophilia\&selectedTitle $=2 \% 7 E 150$ (27.8.2015).

6. Coltart CE, Chew A, Storrar N et al. Schistosomiasis presenting in travellers: a 15 year observational study at the Hospital for Tropical Diseases, London. Trans R Soc Trop Med Hyg 2015; 109: 214-20

7. Vijayan VK, Kilani T. Emerging and established parasitic lung infestations. Infect Dis Clin North Am 2010; 24: 579-602.

8. Mbabazi PS, Andan O, Fitzgerald DW et al. Examining the relationship between urogenital schistosomiasis and HIV infection. PLoS Negl Trop Dis 2011; 5: e1396.

9. Holen $\emptyset$. Schistosomiasis neglisjeres. Tidsskr Nor Lægeforen 2010; 130: 8.

10. Colley DG, Bustinduy AL, Secor WE et al. Human schistosomiasis. Lancet 2014: 383: 2253-64.

11. Clerinx J, Van Gompel A. Schistosomiasis in travellers and migrants. Travel Med Infect Dis 2011: 9: $6-24$

12. Gray DJ, Ross AG, Li YS et al. Diagnosis and management of schistosomiasis. BMJ 2011; 342: d2651.

13. Pavlin BI, Kozarsky P, Cetron MS. Acute pulmonary schistosomiasis in travelers: case report and review of the literature. Travel Med Infect Dis 2012 10: 209-19.

14. Van Nassauw L, Toovey S, Van Op den Bosch J et al. Schistosomicidal activity of the antimalarial drug, mefloquine, in Schistosoma mansoni-infected mice. Travel Med Infect Dis 2008; 6: 253-8.

15. Gundersen SG, Ravn J, Haagensen I. Early detection of circulating anodic antigen (CAA) in a case of acute schistosomiasis mansoni with Katayama fever. Scand J Infect Dis 1992; 24: 549-52.

16. Pérez del Villar L, Burguillo FJ López-Abán J et al. Systematic review and meta-analysis of artemisinin based therapies for the treatment and prevention of schistosomiasis. PLOS ONE 2012; 7: e45867.

Mottatt 7.5. 2015, første revisjon innsendt 19.7. 2015, godkjent 3.9. 2015. Redaktør: Lise Mørkved Helsingen. 